\title{
ASPEK YURIDIS KEWENANGAN PEMERINTAH DAERAH KABUPATEN SUKABUMI PROVINSI JAWA BARAT DALAM PENGELOLAAN KAWASAN GEOWISATA GEOPARK NASIONAL CILETUH- PALABUHAN RATU.
}

\author{
Slamet Riyady \\ Hendrik Fasco Siregar \\ Nurhayati \\ Fakultas Hukum, Universitas Pamulang \\ Email:sangamet281o@gmail.com
}

Received: Jul 2019/Revised: Jul 2019 / Accepted: Ags 2019

\begin{abstract}
Kajian ini bertujuan mengetahui nilai strategis kewenangan dan peran pemerintah daerah sukabumi dalam mengatur serta mengelola kawasan Geowisata Geopark Nasional Ciletuh pada Kabupaten Sukabumi Provinsi Jawa Barat.Geopark National Ciletuh merupakan suatu kawasan luas yang mempunyai unsur - unsur geologi dimana masyarakat setempat dapat menciptakan aktivitas ekonomi, khususnya melalui pariwisata (geowisata), selain itu juga Geopark Nasional Ciletuh resmi ditetapkan menjadi bagian dari jaringan Geopark dunia atau Unesco Global Geopark (UGG) pada tanggal i7 April 2018, oleh Dewan Eksekuti (Executive Boar) UNESCO.

Kata Kunci : Geopark Ciletuh Palabuhanratu, Kewenangan Kabupaten Sukabumi Jawa Barat,Geowisata.
\end{abstract}

\section{ABSTRACT}

This research aims to determine the form of authority and the role of the local government of Sukabumi to organize and manage the region Ciletuh geotourism National Geopark in Sukabumi regency of West Java province, which is where National Ciletuh Geopark is A vast area that has elements of geology where local people can make economic activity, especially through tourism (geotourism), and also national Geopark Ciletuh officially set to be part of the Geopark network World or Unesco Global Geopark (UGG) on April 17, 2018, by the Executive Board (Executive Boar) of UNESCO.

Keywords: Ciletuh Palabuhanratu Geopark, Sukabumi Regency Authority of 


\section{Java,geowisata, \\ PENDAHULUAN}

Geopark Ciletuh-Palabuhanratu resmi ditetapkan menjadi bagian dari jaringan geopark dunia atau Unesco Global Geopark (UGG) tentu hal ini merupakan sejarah baru bagi dunia pariwisata di Jawa Barat. Proses penetapan Geopark Ciletuh-Palabuhanratu menjadi jaringan geopark global UNESCO (UGG) terbilang cepat, dan biasanya proses yang ditempuh sepuluh tahun setelah penetapan geopark nasional.

Melalui Surat Keputusan Komisi Nasional Indonesia untuk UNESCO pada tanggal 2i Juni 2016. Geopark Ciletuh-Palabuhanratu mencakup delapan kecamatan di wilayah Kabupaten Sukabumi, yaitu Kecamatan Cisolok, Cikakak, Palabuhanratu, Simpenan, Ciemas, Waluran, Ciracap, dan Surade, dengan luas wilayah 126 ribu ha atau 30,3\%dari luas wilayah Kabupaten Sukabumi ${ }^{\mathrm{I}}$.

Pengertian Geopark (taman bumi) itu sendiri adalah sebuah wilayah geografi tunggal atau gabungan yang memiliki situs warisan Geologi (geosite), dan bentang alam yang bernilai, terkait aset warisan Geologi (Geoheritage), keragaman (Geodiversity), keaneka ragaman hayati (biodiversity), dan keragaman budaya (cultural diversity), serta dikelola untuk keperluan konservasi, edukasi dan pembangunan perekonomian masyarakat secara berkelanjutan dengan keterlibatan aktif dari masyarakat dan Pemerintah Daerah, sehingga dapat digunakan untuk menumbuhkan pemahaman dan kepedulian masyarakat terhadap bumi dan lingkungan sekitarnya².

Untuk mewujudkannya pembangunan dan pengembangan Geowisata Geopark Ciletuh tentunya perlu didukungan infrastruktur, fasilitas, regulasi atau aturan, kebijakan pemerintahdan program pemberdayaan masyarakat. Geoparkmemiliki semboyan "Memuliakan Bumi, Mensejahterakan Masyarakat”.

Pembangunan danpenumbuhan perekonomian berkelanjutan padakawasan geopark dikembangkan melalui paketpariwisata seperti: geowisata, wisata bahari,ekowisata, wisata petualangan, wisata budaya, wisata belanja, wisata kuliner, dan wisata buatan manusia.3

1 Lampiran keputusan Gubernur Jawabarat No.556/ Kep.941-Rek/2016.tanggal13 Semptember2016.

${ }^{2}$ Pasal 1 Peraturan Presiden Republik Indonesia Nomor 9 Tahun 2019 Tentang Pengembangan Taman Bumi (Geoparak)

${ }^{3}$ http://ciletuhpalabuhanratugeopark.org/profil-ciletuh-palabuhanratu/ diunduh pada tanggal 14 Mei 2019 
Dalam mewujudkan pembangunan dan pertumbuhan ekonomi daerah Geowisata, Pemerintah Daerah Sukabumi berkomitmen dalam menata, melindungi dan mengatur kawasan Geowisata Geopark Nasional Ciletuh melalui aturan-aturan dalam memelihara destinasi wisata Geowisata sangat penting terlebih syarat utama sebuah Geowisata geopark internasional, yaitu pelestarian geodiversity, biodiversity, dan cultural diversit.

Pemerintah Kabupaten Sukabumi dalam hal ini melalui kewenangan yang dimiliknya diharapkan dapat segera membuat aturanaturan hukum termasuk membuat Rencana Detail Tata Ruang (RDTR) terhadap kawasan Geowisata geopark Ciletuh, Penataan yang ideal terhadap Geowisata Geopark Ciletuh harus ditata secara hukum dan penataan kawasan geopark harus ada landasan/payung hukumnya, penetapan RDTR oleh Pemerintah Kabupaten Sukabumi terebut sebagai penjabaran lebih lanjut dari Peraturan Daerah Rencana Umum Tata Ruang Wilayah Jawa Barat.

Saat ini Pemerintah daerah Jawa Barat terus menata dan mengembangkan kawasan geopark Ciletuh karena manfaat yang cukup besar bagi pemerintah daerah dan masyarakat sekitarnya apabila destinasi geowiata ini terus dikembangkan.

Berdasarkan penjelasan di atas Kewenangan dan peran serta Pemerintah Daerah Sukabumi dalam mengatur, menata, dan melindungi serta membuat landasan hukum sebagai payung hukum penataan kawasan geowisata geopark Nasional Ciletuh untuk menjadi geopark global UNESCO adalah sangat penting karena hal tersebut merupakan konsep holistik dari Kewenangan dan peran serta Pemerintah Daerah Sukabumi, guna terciptanya perlindungan, pendidikan dan pembangunan berkelanjutan, serta pemberdayaan masyarakat lokal.

Sangat tidak diharapkan karena minimnya peran serta Pemerintah Daerah Sukabumi dalam mengelola pengembangan Geowisata yang berbasis keragaman alam Geopark Nasional Ciletuh justru pada akhirnya akan menjadi ancaman terhadap kelestarian alam di Geopark Nasional Ciletuh.

Pembangunan kawasan geowisata Ciletuh diharapkan dapat meningkatkan ekonomi masyarakat sekitarnya dan menumbuh kembangkan kesadaran masyarakat untuk melestarikanya, maka dari itu penulis tertarik untuk mengkaji kewenangan dan peran strategis Pemerintah Daerah Sukabumi dalam pengelolaan kawasan Geowisata Geopark Nasional Ciletuh di Kabupaten Sukabumi Provinsi Jawa Barat. 


\section{PERMASALAHAN}

Berdasarkan latar belakang kajian di atas yang telah diuraikan penulis, terdapat pokok permasalahan dalam kajian ini adalah :

I. Bagaimanakah bentuk kewenangan stategis pemerintah daerah sukabumi dalam mengatur, menata dan melindungi Geowisata Geopark Nasional Ciletuh?

2. Bagaimakah produk hukum yang dibuat pemerintah sukabumi dalam menjalankan mengatur, menata dan melindungi Geowisata Geopark Nasional Ciletuh?

\section{METODOLOGI PENELITIAN}

Dalam kajian ini Penulis telah melakukan penelitian yang berada di wilayah Pemerintah Daerah Kabupaten Sukabumi dengan menggunakan metode analisa data deskriptif kualitatif, data yang diperoleh baik dari studi perpustakaan maupun dari Penelitian lapangan dengan cara mengelempokkan dan menyeleksi data dilapangan menurut kualitas kebenarannya yang dihubungkan dengan teori, asas - asas dengan kaidah hukum yang berlaku sebagai dasar kajian kewenangan dan peran stategis pemerintah kabuaten sukabumi dalam mengatur, mengelola serta menata Geowisata Geopark Nasional Ciletuh.

\section{PEMBAHASAN}

Nilai Strategis Kewenangan Pemerintah Provinsi Jawa Barat Mengelola Geopark Nasional Ciletuh - Palabuhanratu

Sejak diberlakukannya otonomi daerah oleh pemerintahan pusat, kini setiap daerah menyelenggarakan urusan pemerintahannya sendiri. Penyerahan wewenang tersebut menjadikan pemerintah daerah mengurus pemerintahan dan kepentingan masyarakat setempat sesuai peraturan perundang-undangan.

Kewenangan Pemerintah Daerah Provinsi sebagaimana penulis jabarkan dimulai dari Perencanaan dan pengendalian pembangunan, dan perencanaan, pemanfaatan, dan pengawasan tata ruang, Penyelenggaraan ketertiban umum dan ketentraman masyarakat, penyediaan sarana dan prasarana umum serta penanganan bidang kesehatan, Penyelenggaraan pendidikan dan alokasi sumber daya manusia potensial dan penanggulangan masalah sosial lintas kabupaten/kota, Pelayanan bidang ketenagakerjaan lintas kabupaten/kota, fasilitasi pengembangan koperasi, usaha kecil, dan menengah termasuk lintas kabupaten/kota, Pengendalian lingkungan hidup, pelayanan pertanahan termasuk lintas 
kabupaten/kota, pelayanan kependudukan, dan catatan sipil, Pelayanan administrasi umum pemerintahan, pelayanan administrasi penanaman modal termasuk lintas kabupaten/kota, Penyelenggaraan pelayanan dasar lainnya yang belum dapat dilaksanakan oleh kabupaten/kota dan urusan wajib lainnya yang diamanatkan oleh peraturan perundang-undangan.

Namun sebelum membahas kewenangan Pemerintah Provinsi lebih jauh perlu kita membahas pengertian dan penjelasan tentang kewenangan sebagaimana penulis penjabaran dibawah ini.

Kewenangan atau wewenang disajajarkan dengan authority atau legal power, aright to command or to act; the right and power of publik officers to require obedience to their orders lawfully issued in scope of their public duties ${ }^{4}$ ( kewenangan atau wewenang adalah kekuasaan hukum, hak untuk memerintah atau bertindak; hak atau kekuasaan pejabat publik untuk memenuhi aturan hukum dalam lingkup melaksanakan kewajiban publik).

Sedang wewenang adalah (I) hak dan kekuasaan untuk bertindak atau melakukan sesuatu; (2) kekuasaan membuat keputusan, memerintah dan melimpahkan tanggung jawab kepada orang lain. ${ }^{5}$

Konsep teoritis tentang kewenangan.H.D.Stoud, seperti dikutip Ridwan $\mathrm{HB}$, menyajikan pengertian tentang Kewenangan adalah "Keseluruhan aturan-aturan yang berkenaan dengan perolehan dan penggunaan wewenang pemerintah oleh subjek hukum public di dalam hubungan hukum public". ${ }^{6}$

Sedangkan Indroharto, mengemukakan tiga macam kewenangan yang bersumber dan peraturan perundang-undangan. Kewenangan itu, meliputi: atribusi; delegasi; dan mandat. ${ }^{7}$ Atribusi itu sendiri adalah pemberian wewenang pemerintahan oleh pembuat Undang - Undang kepada organ pemerintahan berdasarkan Undang - Undang No.3o Tahun 2014 tentang Administrasi Pemerintahan ( UU Administrasi Pemerintahan ), yang mempunyai makna pemberian Kewenangan kepada Badan dan / atau Pejabat Pemerintahan oleh Undang - Undang Dasar Negara Republik Indonesia Tahun 1945 atau Undang - Undang.

Delegasi adalah pelimpahan wewenang pemerintahan dari suatu organ pemerintahan kepada organ pemerintahan lainya Berdasarkan UU Administrasi Pemerintahan, yang mempunyai arti Pelimpahan

${ }^{4}$ Nurbasuki winarmo, Penyalahgunaan wewenang dan Tindak pidana korupsi, laksbang mediatama, Yogyakarta,2008, hal 65.

5Anton M. Moeliono, dkk., Kamus Umum Bahasa Indonesia, Jakarta, Balai Pustaka, 1995, hal 533

6 Ridwan HR.Hukum Administrasi Negara, Jakarta: Raja Grafindo Persada,2008, hal.110

${ }^{7}$ IbId, hal 104 
Kewenangan dari Badan dan / atau pejabat pemerintahan yang lebih rendah dengan tanggungjawab dan tanggung gugat beralih sepenuhnya kepada penerima delegasi.

Sedangkan mandat itu sendiri mengizinkan kewenangannya dijalankan oleh organ lain atas namanya, yang berdasarkan UU Administrasi Pemerintahan mandate memiliki makna pelimpahan kewenangan dari Badan dan / atau Pejabat Pemerintahan yang lebih tinggi kepada Badan dan / atau Pejabat Pemerintahan yang lebih rendah dengan tanggungjawab dan tanggung gugat tetap berada pemberi mandat ${ }^{8}$.

Berkaitan pengertian pemberian kekuasaan diatas menurut hemat penulis dalam hubunganya dengan administrasi negara pemerintah Provinsi Jawa Barat tentu memiliki kewenangan yang bersifat atribusi dalam mengelola potensi pariwisata yang berbentuk geopark sebagaimana yang tercantum dalam Pasal 29 Undang-Undang Republik Indonesia Nomor io Tahun 2009 Tentang Kepariwisataan yang intinya menyatakan menggariskan pemerintah provinsi berwenang untuk menyusun dan menetapkan rencana induk pembangunan kepariwisataan provinsi; mengoordinasikan penyelenggaraan kepariwisataan di wilayahnya;melaksanakan pendaftaran, pencatatan, dan pendataan pendaftaran usaha pariwisata; menetapkan destinasi pariwisata provinsi; menetapkan daya tarik wisata provinsi memfasilitasi promosi destinasi pariwisata dan produk pariwisata yang berada di wilayahnya; memelihara aset provinsi yang menjadi daya tarik wisata provinsi; dan mengalokasikan anggaran kepariwisataan ${ }^{9}$.

Setelah mendapatkan kewenangan yang bersifat atribusi yang dimiliki oleh Pemerintah Provinsi Jawa Barat dalam menyusun dan menetapkan induk pembangunan Geowisata Geopark Ciletuh Palabuhanratu, Pemerintah Provinsi Jawa Barat juga membentuk suatu badan yang mempunyai tugas melaksanakan pelestarian, pengendalian, pemanfaatan kawasan lindung khususnya kawasan Geopark Nasional Ciletuh di daerah Kabupaten Sukabumi yang disebut Badan Pengelola Kawasan Geopark Nasional Ciletuh, yang bertujuan menjamin penyelenggaraan pengelolaan pembangunan, pengembangan kawasan lindung khususnya Kawasan Geopark Nasional ciletuh di daerah Kabupaten Sukabumi.

Adapun Peraturan Gubernur Jawa Barat Nomor: 20 Tahun 2016 Tentang Badan Pengelolaan Kawasan Geopark Nasional Ciletuh Di

${ }^{8}$ Ibid, hal $105-107$

${ }^{9}$ Pasal 9 Undang-Undang Republik Indonesia Nomor 10 Tahun 2009 Tentang Kepariwisataan 
Daerah Kabupaten Sukabumi dengan tugas pokok dan fungsi sebagaimana tercantum dalam Pasal 6 nampak sangat jelas peran dan kewenangan Pemerintah Provinsi Jawa Barat secara dominan dalam membangun Kawasan Geopark Nasional Ciletuh - Palabauhanratu, selain membentuk Badan Pengelola Kawasan Geopark Nasional Ciletuh untuk menjamin Badan Pengelolan Kawasan Geopark Nasional berjalan dengan baik, Gubernur Provinsi Jawa Barat juga mengelurkan beberapa keputusan stategis dan potensial diantaranya adalah : Keputusan Gubernur Jawa Barat Nomor ; 556.05/kep-1288-Rek/2015 Tentang Tim Koordinasi Kawasan Geopark Ciletuh Di Daerah Kabupaten Sukabumi; Keputusan Gubernur Jawa Barat Nomor ; 556.05/kep-1289-Rek/2015 Tentang Tim Operasional Percepatan Pengembangan Kawasan Ciletuh Di Daerah Kabupaten Sukabumi Menjadi Kawasan Geopark; Keputusan Gubernur Jawa Barat Nomor ; 556. /Kep-456-Rek/2016 Tentang Susunan Personalia Badan Pengelola Kawasan Nasional Geopark Ciletuh Di Daerah Kabupaten Sukabumi;

Setelah lahirnya Badan Pengelolan Kawasan Nasional Geopark Ciletuh dengan beberapa keputusan Gubernur di atas, Pemerintah Provinsi Jawa Barat menyadari akan pentingnya pengembangan Geopark di Jawa Barat yang efektif dilakukan dengan cara koordinasi, dan sinkronisasi pelaksanaan yang dilakukan secara kolaborasi pemangku kepentingan oleh sebab itu demi tercapainya pengembangan kawasan geopark tersebut Gubernur Jawa Barat mengeluarkan Peraturan Gubernur Jawa Barat Nomor : 72 Tahun 2018 Tentang Pengembangan Kawasan Geopark Di Kawasan Provinsi Jawa Barat, yang mana dilakukan dengan cara kolaborasi dengan pemangku kepentingan terutama Pemerintah Daerah / Kota yang memilki potensi warisan geologi, keanekaragaman geologi, keaneka ragaman hayati dan keaneka ragaman budaya.

Adanya kolaborasi atau kerja sama antar pemangku kepentingan dengan Pemerintah Provinsi Jawa Barat diharapkan sudah sesuai dengan Peraturan Daerah Nomor 22 Tahun 2010 Tentang Rencana Tata Ruang Wilayah Provinsi Jawa Barat Tahun 2009-2029, Pasal 35, bahwa kawasan lindung geologi, terdiri atas: a. Kawasan konservasi lingkungan geologi, yang antara lain kawasan cagar alam geologi, salah satunya pada point huruf (c) menetapkan bahwa Kawasan Geologi Ciletuh, terletak di Kabupaten Sukabumi, sebagai Kawasan Cagar Alam Geologi (KCAG).

Menurut hemat penulis karena dipandang bahwa di kawasan tersebut memiliki sejumlah keunikan geologi. Lalu, Kab. Sukabumi menetapkan dengan Peraturan Daerah Kabupaten Sukabumi Nomor II Tahun 20I0 Tentang Rencana Pembangunan Jangka Menengah Kabupaten 
Sukabumi Tahun 2010-2015, dan Pergub No 20 tahun 2016 tentang Badan Pegelolaan Kawasan Geopark Nasional Ciletuh Daerah Kabupaten Sukabumi.

\section{Kewenangan Pemerintah Daerah Sukabumi Mengelola Kawasan Geowisata Geopark Nasional Ciletuh .}

Kabupaten Sukabumi memiliki potensi geologi dan Pariwisata dikawasan Geopark Ciletuh dengan kelompok batuan yang memiliki nilai keunikan, kelangkaan, keragaman, serta estetika yang dapat menimbulkan daya tarik wisatawan lokal maupun asing, mengingat Geopark Ciletuh amanat peraturan Pemerintah Daerah Jawabarat Nomor 2 Tahun 2002 Tentang Perlindungan Lingkungan Geologi yaitu melindungi kawasan kawasan lindung Geologi yang ada dijawa barat termasuk kawasan ciletuh, maka sangatlah dibutuhkan peranan Pemerintah Kabupaten Sukabumi dalam membantu pengelolaan Geowisata yang berada dalam Geopark Ciletuh tersebut.

Salah satu objek Geowisata yang berada dalam wilayah Pemerintahan Kabupaten Sukabumi adalah macam - macam keragaman diantaranya adalah : Keragaman Geologi ; Keragaman geologi menurut Gray di definisikan sebagai rentang keragaman keistimewaan dan tampilan dari geologi ( batuan, mineral dan fosil), pembentukan tanah, yang meliputi kumpulannya, hubungan, sifat, atau karakter yang dimiliki, yang mencangkup semua material, strktur dan proses yang menyusun dan mengendap dan membentuk bumi seperti air terjun sodong dan air terjun cumarunjing. Keragaman hayati ; Keragaman hayati adalah istilah yang diberikan berbagai kehidupan dibumi dimana kehidupan tersebut meliputi semua spesies tanaman, hewan, dan mikroogarnisme serta ekosistem dimana mereka hidup dan berinteraksi contohnya saja adanya ekosistem yang alamiah dan ekosistem yang buatan manusia, ekosistem alamiah itu sendiri yang terbentuk secara alamiah seperti ekosistem sungai, gurun dan terumbu karang sedangkan ekosistem buatan manusia contohya adalah ekosistem sawah, ekosistem perkebunan, ekosistem bendungan dan ekosistem lainnya, Keragaman Budaya ; Ini adalah salah satu pilar sangat penting di dalam Geopark sendiri karena untuk meningkatkan kesejahteraan masyarakat setempat disekitar Geopark, karena budaya selaras dengan nilai - nilai kemanusian dan memperkuat kehiduan masyarakat yang sehat, dan menadi indikator kesejahteraan masyarakat.

Kawasan Geowisata Geopark Ciletuh Palabuhanratu memiliki konsep yang utama konservasi, dengan demikian kelestarian akan 
keragaman geologi dan hayati haruslah dikelola dengan baik sehingga tidak terjadi kerusakan, Pemerintah Kabupaten membuat kebijakan yang dikeluarkan berdasarkan Surat Keputusan Bupati Sukabumi Nomor 556/Kep.555-Disparbudpora/2015 Tentang Penetapan Kawasan Geopark Ciletuh, yang mana sebagian besar situs Geologi merupakan bagian dari Cagar Alam Cibanteng dan Suaka Margasatwa Cikepuh yang dikelolah oleh BBKSDA Jawa Barat. Saat ini situs - situs tersebutpun sedang diajukan Sebagai Kawasan Cagar Alam Geologi pada Kementerian Energi dan Sumberdaya Mineral.

Adapun kewenangan yang dimiliki Pemerintah Kabupaten Sukabumi dalam mengelola Geowisata Geopark Ciletuh bentuknya delegasi yang diatur dalam Keputusan Gubernur Jawa Barat Nomor : 556/ Kep-456- Rek/2016. Namun Sebelum membahas kewenangan yang berbentuk delegasi dari Pemerintah Provinsi dalam mengelola Geowisata Geopark Nasional Ciletuh peneliti ingin memperjelas dan mempertegas konsep yuridis delegasi yang dimaksudkan dalam nilai strategis kewenangan pemerintah daerah Sukabumi.

Secara Yuridis normative delegasi adalah suatu pelimpahan wewenang dan tanggung jawab formal kepada orang lain untuk melaksanakan kegiatan tertentu ${ }^{\text {io }}$. Merujuk pengertian dia atas menurut penulis secara singkat delegasi dapat dikatakan sebagai pemberian sebagian pertanggungjawaban, yang dijelaskan dalam suatu penjabaran deskripsi tugas dalam organisasi, dalam penelitian ini maksud delegasi disini adalah pendegelasian wewenang oleh Pemerintahan Provinsi Jawa Barat kepada Pemerintahan Daerah Kabupaten Sukabumi dalam pengelolaan Geowisata Geopark Nasional Ciletuh.

Kewenangan Pemerintah Daerah Kabupaten dan Kota adalah sebagai berikut: Perencanaan dan pengendalian pembangunan, perencanaan, pemanfaatan, dan pengawasan tata ruang., salah satunya adalah penyediaan sarana dan prasarana umum, berkaitan dengan kewenangan dan peran Pemerintahan Daerah Sukabumi dalam pengelolaan kawasan geowisata Geopark Nasional Ciletuh Kabupaten Sukabumi yang paling menonjol adalah rencana induk dalam perencanaan pembangunan dan pengembangan Kawasan Geopark Ciletuh sesuai dengan Peraturan Daerah Kabupaten Sukabumi Nomor : 22 Tahun 2012 Tentang Rencana Tata Ruang Wilayah Kabupaten Sukabumi Tahun 2012- 2032.

${ }^{10}$ Satria,pengertiandelegasi,12November2012, diaksesdarihhtp//satriogosatria.blogspo t.co.id/2019/05/pengertian delegasi-,htl 
Tujuan dari penataan ruang oleh Pemerintah Daerah Kabupaten Sukabumi adalah mewujudkan tata ruang yang efesien, Pruduktif, berkelanjutan, dan berdaya saing dibidang Pariwisata dalam kawasan Geopark untuk memajukan serta mensehaterakan masyarakat Daerah Kabupaten Sukabumi.

Adapun kewenangan Pemerintah Daerah Sukabumi dalam mengelola Geopark Ciletuh antara lain:

I. Penyiapan lahan sesuai dengan Rencana Tata Ruang Wilayah Kabupaten / kota;

2. Pembangunan kawasan Geopark;

3. Sosialisasi keberadaan Geopark;

4. Pelaksanaan promosi Geopark;

5. Pemeliharaan kelestarian Geopark;

6. Pemeliharaan ketentraman, ketetertiban dan keindahan Geopark;

7. Pengembangan perekonomian rakyat;

8. Peningkatan pemberdayaan masyarakat;

9. Pelaksanaan lainya sesuai dengan ketentuan peraturan perundang - undangan. ${ }^{\text {II }}$

Selain sebagai induk rencana atau sebagai penetapan rencana kaawasan Geopark Ciletuh, Pemerintah Daerah Kabupaten Sukabumi juga mepunyai kebijakan membentuk Badan Pengelola Kawasan Geopark Ciletuh Kabupaten Sukabumi sebagaimana Keputusan Bupati Sukabumi Nomor: 556/Kep-.559-disparbudpora/2015 Tentang Badan Pengelola Kawasan Geoprak Ciletuh Kabupaten Sukabumi, dengan struktur keanggotaan dan struktur keanggotaan, yang mempunyai tugas pokok: Merumuskan dan Menetapkan kebijakan umum serta teknis program penataan, Pembangunan dan Pengelolaan di Kawasan Geopark Ciletuh ; dan Sinergitas antar program/kegiatan antara Pemerintah, Pemerintah Daerah, Masyarakat dan Mitra di Kawasan Geopark Ciletuh. Sedangkan untuk Fungsi : Mengkoordinasikan semua kegiatan di lokasi Kawasan Geopark Ciletuh ; Menggerakkan Institusi terkait Kecamatan dan Desa dalam pelaksanaan kegiatan penataan di Kawasan Geopark Ciletuh ; Monitoring dan evaluasi pelaksanaan kegiatan penataan dan pengelolaan di Kawasan Geopark Ciletuh ; Melaporkan kegiatan pelaksanaan kegiatan di Kawasan Geopark Ciletuh kepada Bupati.

${ }^{11}$ Pasal 9 Peraturan Gubernur Jawa Barat Nomor : 72 Tahun 2018 Tentang Pengembangan Kawasan Geopark Di Kawasan Provinsi Jawabarat 
Selain kewenangan dalam membentuk Badan Pengelola Geopark Ciletuh Kabupaten Sukabumi, Pemerintah Kabupaten Sukabumi juga mempunyai kebijakan memungut retribusi tempat Rekreasi dan olahraga, atas pelayanan tempat rekreasi, pariwisata, dan olahraga yang disediakan, dimiliki / dikelola oleh Pemerintah Daerah.

Setelah penulis teliti dan kaji terdapat objek yang dapat dipungut retribusi itu salah satunya adalah : kawasan Geopark CiletuhPalabuhanratu, meliputi: teluk Palabuhanratu (mulai dari pantai Palabuhanratu sampai dengan pantai Cibareno); tempat Rekreasi Cipanas Cisolok; cottage Cipanas Cisolok; pantai loji, Pantai Sangrawayang dan Pantai Cipunaga; pantai Ujung Genteng meliputi : Ujung Genteng, Cibuaya dan Pangumbahan; pantai Minajaya Surade; kawasan Ciletuh meliputi : Pantai Palangpang, Curug Awang, Curug Cimarinjung, Curug Sodong, Curug Puncak Manik dan Puncak Dharma;

a) curug Cikaso;

b) kawasan Wisata Alam Perbawati;

c) tempat Rekreasi Pondok Halimun;

d) bumi Perkemahan Pondok Halimun;

e) cottage Pondok Halimun;

f) tempat Rekreasi Cinumpang;

g) bumi Perkemahan Cinumpang;

h) cottage Cinumpang;

i) kolam Renang Cinumpang;dan

j) bumi perkemahan Palagan Bojongkokosan. ${ }^{12}$

Kebijakan memungut retribusi tempat Rekreasi dan olahraga, atas pelayanan tempat rekreasi, pariwisata, dan olahraga yang disediakan, dimiliki / dikelola oleh Pemerintah Daerah tentunya akan digunakan untuk meningkatkan kualitas pelayanan dan pendapat pemerinta Daerah. Kendala Yang Dihadapi Pemerintah Daerah Kabupaten Sukabumi Dalam Mengelola dan Mengembangkan Geowisata Geopark Nasional Ciletuh Palabuhanratu

Setelah Geopark Nasional Ciletuh telah menyandang predikat UGG, atau sebagai bagian dari Geopark dunia atau Unesco Global Geopark, Pemerintah Provinsi Daerah Jawa Barat dan Pemerintah Kabupaten Sukabumi mempunyai kendala dalam mengelola bahkan mengembangkan Geopark Nasional Ciletuh Palabuhanratu, yang dapat di jabarkan berdasarkan wawancara tim penulis dengan beberapa pihak dan

${ }^{12}$ Pasal 3 Peraturan daerah kabupaten sukabumi Nomor 7 tahun 2018 Tentang Retribusi tempat rekreasi dan olahraga 
anggota Badan Pengelola Geopark Nasional Ciletuh, dan dari hasil wawancara penulis dapat menemukan kendala yang muncul diantaranya adalah :

Pertama tentang Tupoksi dari taman dunia dan Pariwisata, yang mana dalam mengelola Geopark itu sendiri Pemerintah Daerah terjabak dalam regulasi dan kebijakan yang tidak sinkron dibuat oleh beberapa pemangku kepentingan misalnya saja tentang Geopark dimaknai sebagai ranah geologi semata, dalam hal ini adalah kewenangan menteri mineral sedangkan Pariwisata itu lebih kepada kementerian Pariwisata, selain tugas pokok dan fungsi yang berbeda padahal apabila kita tarik keduanya mempunyai atau berada dalam satu kawasan hanya saja untuk Taman Bumi atau Geopark diperlukan konservasi, edukasi ,dan pemberdayaan masyarakat.

Selain itu kendala Pemerintah Kabupaten Sukabumi dalam Mengelola Geowisata Geopark yang paling mendasar adalah tentang dana dalam mengelola harus menunggu persetujuan pemerintah Provinsi Jawa Barat dan kurangnya kebebasan Pemerintah Kabupaten Sukabumi mengelola Geeopark.

Sebagai penutup tulisan ini temuan yang penulis dapatkan dan tak kalah pentingnya adalah dari segi Agraria/ pertanahan dan kepemilikan tanah adat/ rakyat dan kepentingan Pemerintah daerah dalam pengembangan kawasan, yaitu kepemilikan lahan atau bentangan alam taman bumi atau geopark yang sebagian masih dikuasai oleh warga sekitarya sehingga dalam mengelola geopark harus ada pembebasan yang mengelurkan dana besar, dimana lahannya dikatakan produktif, serta pengetahuan masyarakat setempat yang masih minim tentang Geopark sehingga masyarakatnya belum menyadari akan pentingnya Konservasi taman alam atau Geopark itu sendiri.

\section{KESIMPULAN}

Dari hasil kajian penulis dapat disimpulkan :

I. Kewenangan yang dimiliki Pemerintah Kabupaten Sukabumi dalam mengelola Geowisata Geopark Ciletuh bentuknya delegasi yang diatur dalam Keputusan Gubernur Jawa Barat Nomor : 556/ Kep456- Rek/2016.

2. Produk hukum yang dibuat pemerintah Sukabumi dalam menjalankan mengatur, menata dan melindungi Geowisata Geopark Nasional Ciletuh adalah dalam bentuk Keputusan Bupati Sukabumi Nomor ;556/Kep-.559-disparbudpora/2015 Tentang Badan 
Pengelola Kawasan Geoprak Ciletuh Kabupaten Sukabumi, dengan struktur keanggotaan yang mempunyai tugas dan fungsi masing masing.

3. Peran Pemerintah Kabupaten Sukabumi adalah sebagai induk rencana penetapan kawasan Geopark sebagaimana masterplain sesuai dengan Peraturan Gubernur Jawa Barat Nomor : 72 Tahun 2018 Tentang Pengembangan kawasan Geopark di daerah Provinsi Jawa Barat.

\section{DAFTAR PUSTAKA}

Philipus M. Hadjon, "Tentang Wewenang Pemerintahan (Bestuurbevoegdheid), Pro Justitia Tahun XVI Nomor I Januari 1998.

Ridwan HR. Hukum Administrasi Negara, Jakart, RajaGrafindo Persada, 2008.

Harris Soche,Supremasi hukum dan prinsip demokrasi di Indonesia, PT.Hanindita, Jogjakarta,1985.

M.Hadjon, Phillipus. Perlindungan hukum bagi Rakyat Indonesia, PT.Bina Ilmu, Surabaya,I987

Salim HS dan Nurbaini,E.S.,Penerapan teori hukum Hukum pada Penelitian Tesis dan Disertasi, PT.Raja Grafindo Persada, Jakarta, 2014 .

Sinambela Mahadi,Azhari, Dilema Otonomi Daerah dan masa depan Nasionalisme Indonesia, Balairung \&co, Jogjakarta, 2003.

Nurbasuki winarmo, Penyalahgunaan wewenang dan Tindak pidana korupsi, laksbang mediatama, Yogyakarta,2008, hal 65

Marbun,M.Mahfud MD, Pokok-Pokok Hukum Administrasi Negara,Liberty, Yogyakrta,1987

M.Manulang, Dasar-dasar Manajemen, Ghalia Indonesia, Jakarta,1992.

Solly Lubis, Landasan dan Teknik perundang-Undangan,mandar maju, Bandung, 1989.

Parlindungan,AP.,Komentar atas Undang-Undang Pokok Agraria,Mandar Maju,Bandung,1993.

Firman TE, Hukum Perlindungan Konsumen, Setara Press, Jakarta, 2016.

Rasjidi,lili, Fisafat Hukum, Remadja karya,Bandung,1988

Jurnal

Jurnal Inovatif, Volume VII Nomor III September 2014, Judul : Perlindungan Hukum Terhadap Geopark Merangin Jambi Yang Berpotensi Menjadi Anggota Global Geopark Network (GGN) UNESCO. Penulis Rahayu Repindowaty H, S.H., LL.M. 
Jurnal Manajemen Resort dan Leisure Vol.13, No.I, April 2016, Judul : Pengembangan Geopark Ciletuh Berbasis Partisipasi Masyarakat sebagai Kawasan Geowisata di Kabupaten Sukabumi. Penulis Darsiharjo, Upi Supriatna, Ilham Mochammad Saputra

Internet

http://ciletuhpalabuhanratugeopark.org/profil-ciletuh-palabuhanratu/ diunduh pada tanggal i4 Mei 2019

Satria,pengertiandelegasi,12November2or2, diaksesdarihhtp//satriogosatria. blogspot.co.id/2019/o5/pengertian delegasi-,htl

Peraturan Perundang-Undangan

Undang-Undang No.II tahun 1950 tentang Pembentukan Provinsi Jawa barat jo. Undang-Undang No.20 tahun 1950 tentang Pemerintahan Jakarta Raya.

Undang-Undang Nomor 26 Tahun 2007 Tentang Penataan Ruang.

Undang-Undang Nomor 32 tahun 2009 tentang Perlindungan dan Pengelolaan Lingkungan Hidup.

Undang-undang Nomor 23 Tahun 2014 Tentang Pemerintahan Daerah.

Peraturan Pemerintah Nomor 26 tahun 2008 tentang Rencana Tata ruang wilayah Nasional. 

